\title{
KANDUNGAN I NFORMASI TAMBAHAN DARI LABA, MODAL KERJ A OPERASI DAN ARUS KAS PADA PERUSAHAAN MANUFAKTUR GO PUBLIC TAHUN 1997 - 2001
}

\author{
Hadri Kusuma \\ Fakultas Ekonomi Universitas Islam Indonesia \\ Handojo Budi Rahardjo \\ PT. Bank Central Asia Yogyakarta
}

\begin{abstract}
Abstrak
Penelitian bertujuan untuk mengetahui secara empiris kandungan informasi tambahan dari laba, modal kerja operasi dan arus kas operasi perusahaan manufaktur publik dalam memprediksi return saham. Penelitian ini menggunakan 78 perusahaan manufaktur yang terdaftar di BEJ, dengan periode pengambatan tahun 1997-2001.

Hasil penelitian ini menunjukkan bahwa, (1) Perubahan laba memiliki kandungan informasi tambahan dalam memprediksi return saham. Hal ini menunjukkan bahwa perubahan laba dapat digunakan sebagai variabel prediktor dalam memprediksi return saham. Tinggi rendahnya return saham tergantung pada tinggi rendahnya perubahan laba, (2) Perubahan modal kerja operasi memiliki kandungan informasi tambahan dalam memprediksi return saham. Hasil ini menunjukkan bahwa perubahan modal kerja operasi dapat digunakan sebagai variabel prediktor dalam memprediksi return saham. Tinggi rendahnya return saham tergantung pada tinggi rendahnya perubahan modal kerja operasi, (3) Perubahan arus kas operasi memiliki kandungan informasi tambahan dalam memprediksi return saham. Hal ini berarti bahwa perubahan arus kas operasi dapat digunakan sebagai variabel prediktor dalam memprediksi return saham. Tinggi rendahnya return saham tergantung pada tinggi rendahnya perubahan arus kas operasi.
\end{abstract}

Keywords: Arus kas operasi, return saham, laba, modal kerja operasi

\section{LATAR BELAKANG MASALAH}

Hingga kini, konsep laba dan arus kas selalu menjadi bahan perdebatan dan perbincangan yang menarik bagi para akuntan dan analisis keuangan. Hal ini terlihat dari banyak penelitian-penelitian yang masih mempelajari secara empiris variabel-variabel tersebut.

FASB menyatakan bahwa informasi laba yang dihitung dengan dasar akrual pada umumnya dapat menunjukkan informasi mengenai kinerja perusahaan yang lebih baik dibandingkan dengan informasi penerimaan dan pengeluaran kas. Namun sebagian analisis keuangan meragukan akurasi dan obyektifitas informasi akuntansi karena komponen akrualnya. Laba akuntansi mengandung komponen-komponen akrual yang berbeda antara satu perusahaan dengan perusahaan lainnya sehingga sulit diperbandingkan. Dalam analisis investasi, pada umumnya para analisis keuangan lebih banyak menggunakan informasi yang berkaitan dengan penerimaan dan pengeluaran kas, karena variabel-variabel ini lebih mencerminkan likuiditas dari pada informasi laba 
akuntansi. Informasi ini dapat ditemukan dalam laporan arus kas yang sudah menjadi bagian yang integral dari laporan keuangan perusahaan publik di Indonesia sejak berlakunya Standar Akuntansi Keuangan (SAK) pada tanggal 1 Januari 1995.

Tujuan utama dari laporan arus menurut PSAK Nomor 2 Tahun 2002 adalah untuk memberikan informasi historis mengenai perubahan kas dan setara kas dari suatu perusahaan melalui laporan arus kasa yang mengklasifikasikan arus kas berdasarkan aktivitas operasi, investasi maupun pendanaan (financing). Menurut Munawir (2002; 113); laporan arus kas disusun untuk menunjukkan perubahan kas selama satu periode dan memberikan penjelasan mengenai alasan perubahan tersebut dengan menunjukkan dari mana sumber penerimaan kas dan untuk apa penggunaannya. Dengan demikian diharapkan para pengguna laporan arus kas dapat menilai kemampuan perusahaan dalam menghasilkan kas dan setara kas dari kegiatan bisnisnya.

Menurut PSAK (2002), terdapat beberapa manfaat yang dapat diperoleh pengguna laporan arus kas antara lain:

1. Laporan arus kas dapat memberikan informasi yang memungkinkan para pemakai untuk mengevaluasi perubahan dalam aktiva bersih perusahaan.

2. Laporan arus kas dapat memberikan informasi yang memungkinkan para pemakai untuk mengevaluasi perubahan struktur keuangan perusahaan (termasuk likuiditas dan solvabilitas).

3. Informasi arus kas historis sering digunakan sebagai indikator dari jumlah, waktu dan kepastian arus kas masa depan.

Kemampuan data arus kas historis dalam memprediksi arus kas masa depan telah diteliti oleh Finger (1994). Hasil penelitiannya membuktikan bahwa arus kas lebih baik dibandingkan laba dalam memprediksi arus kas masa depan dalam jangka pendek. Sedangkan dalam jangka panjang kemampuan arus kas relatif setara dengan laba. Namun keduanya merupakan prediktor yang signifikan terhadap arus kas masa depan. Sedangkan di Indonesia, penelitian serupa juga telah dilakukan oleh Parawiyati dan Baridwan (1998) dengan sedikit modifikasi. Penelitian ini mengambil sampel 288 laporan keuangan perusahaan manufaktur yang telah terdaftar di Bursa Efek Jakarta (BEJ) untuk periode tahun 19891994. Senada dengan hasil penelitian pendahulunya, kesimpulan yang diperoleh dari penelitian ini menyatakan bahwa laba dan arus kas merupakan prediktor yang baik untuk meramalkan arus kas masa depan. Akan tetapi laba masih lebih baik dalam memprediksi arus kas masa depan dibandingakan dengan prediktor arus kas. Temuan ini mengindikasikan yang bermanfaat sebagai bahan pertimbangan dalam pembuatan keputusan bagi para analisis, investor dan manajer dalam rangka mengetahui prospek kinerja perusahaan. Selain sebagai prediktor arus kas masa depan, informasi laba dan arus kas juga membawa kandungan informasi ke pasar modal sebagai konsekuensi dari manfaatnya dalam memprediksi arus kas masa depan.

Penelitian yang dilakukan oleh Ashiq Ali (1994) menunjukkan selain informasi arus kas dan laba, informasi mengenai modal kerja dari operasi (working capital from operations) juga memiliki kandungan informasi. Penelitian ini akan mereplikasi penelitian yang dilakukan Ashi Ali tersebut dengan kondisi perusahaan dan pasar modal Indonesia.

\section{TUJUAN PENELITIAN}

1. Untuk mengetahui secara empiris kandungan informasi tambahan dari laba perusahaan manufaktur publik dalam memprediksi return saham.

2. Untuk mengetahui secara empiris kandungan informasi tambahan dari modal kerja operasi perusahaan manufaktur publik dalam memprediksi return saham. 
3. Untuk mengetahui secara empiris kandungan informasi tambahan dari arus kas perusahaan manufaktur publik dalam memprediksi return saham.

\section{KAJIAN PUSTAKA Laporan Keuangan}

Baridwan (1997) menyatakan bahwa sesuai dengan Statement of Financial Accounting Concept (SFAC) nomer 5, Recognition and Measurement in Financial Statement of Business Interprises, satu set penuh laporan untuk satu periode harus menunjukkan:

1. Posisi keuangan pada akhir periode

2. Earning (laba bersih) untuk periode itu

3. Laba komprehensif (total perubahan modal yang ebrasal dari pemilik) untuk periode itu.

4. Aliran kas selama periode itu.

5. Investasi oleh dan distribusi kepada pemilik selama periode itu.

Di Indonesia, berkaitan dengan perkembangan pasar modal, regulasi informasi diatur dalam undang-undang no. 8 tahun 1985, mengenai pelaporan dan keterbukaan informasi dan peraturan Pasar Modal No. KEP/80/PM/1996, mengenai laporan keuangan periodik.

Kedua peraturan tersebut di atas mengharuskan perusahaan publik menyampaikan laporan keuangannya secara periodik dengan tepat waktu. Publikasi laporan keuangan teraudit dan laporan keuangan semi tahunan yang tidak teraudit bersifat wajib. Laporan keuangan harus dibuat berdasar Standar Akuntansi Keuangan (SAK) dan terdiri dari neraca, laporan rugi laba dan laporan arus kas serta pengungkapan mengenai kebijakan akuntansi.

\section{Hipotesis Pasar Modal Efisien}

Konsep pasar modal yang efisien (efficient capital markets) menjadi dominan pada tahun 1960-an di kalangan akademis. Pada saat itu istilah pasar modal efisien se- ring dipergunakan dengan arti atau maksud yang berbeda-beda. Sebagai misal, di kalangan para pelaku di bursa efek yang mengartikan pasar modal efisien sebagai pasar yang menyediakan jasa-jasa yang diperlukan oleh para pemodal dengan biaya yang minimal. Sementara itu efisiensi pasar dapat dibedakan menjadi internal dan external efficiency. External efficiency menunjukkan bahwa pasar berada dalam keadaan keseimbangan sehingga keputusan perdagangan saham berdasarkan atas informasi yang tersedia di pasar tidak bisa memberikan tingkat keuntungan diatas tingkat keuntungan keseimbangan. Internal efficiency menunjukkan bahwa pasar modal bukan hanya memberikan harga yang "benar", tetapi juga memberikan berbagai jasa yang diperlukan oleh para pembeli dan penjual dengan biaya serendah mungkin (Foster, 1986: 313).

Secara formal pasar modal yang efisien didefinisikan sebagai pasar yang harga sekuritas-sekuritasnya telah mencerminkan semua informasi yang relevan. Semakin cepat informasi baru tercermin pada harga sekuritas, makin efisien pasar modal tersebut. Dengan demikian para pemodal sulit untuk memperoleh tingkat keuntungan di atas normal (Husnan, 1993: 214). Fama dalam artikelnya mengatakan bahwa pasar modal efisien jika harga saham-sahamnya mencerminkan semua informasi yang dipublikasikan (Jogiyanto, 1998: 284).

Menurut Foster (1986: 301), pasar modal yang efisien difokuskan pada variabel pasar keseluruhan, seperti harga saham atau return sekuritas, dan bukannya pada perilaku individual. Tingkat harga sekuritas merupakan hasil dari sejumlah faktor-faktor ekonomi seperti, tingkat suku bunga, inflasi, dan pengharapan-pengharapan berkenaan dengan kondisi ekonomi. Kondisi-kondisi yang harus terpenuhi untuk mencapai pasar yang efisien adalah:

1. Tidak adanya biaya transaksi dalam perdagangan saham. 
2. Seluruh informasi tersedia bagi para partisipan dalam pasar modal dengan tanpa adanya biaya untuk mendapatkan informasi tersebut.

3. Adanya pengharapan yang homogen dari semua investor mengenai dampak dari informasi yang tersedia.

\section{Efisiensi Pasar}

Secara umum, efisiensi pasar (market efficiency) didefinisikan oleh Beaver (1989) sebagai hubungan antara harga-harga sekuritas dengan informasi. Secara detail, efisiensi pasar dapat didefinisikan dalam beberapa macam definisi, yaitu: (1) definisi pasar didasarkan pada nilai intrinsik sekuritas, (2) definisi efisiensi pasar didasarkan pada akurasi dari harga sekuritas (Fama, 1970), (3) definisi efisiensi pasar didasarkan pada distribusi dari informasinya (Beaver, 1989) dan (4) definisi efisiensi pasar didasarkan pada proses dinamik (Jones, 1995).

Konsep awal dari efisiensi pasar yang berhubungan dengan informasi laporan keuangan berasal dari praktek analisis sekuritas yang mencoba menemukan sekuritassekuritas dengan harga yang kurang benar (mispriced). Sekuritas-sekuritas yang dihargai kurang benar (mispriced) merupakan sekuritas-sekuritas yang harganya menyimpang dari nilai intrinsiknya atau nilai fundamentalnya. Untuk konteks seperti ini, maka efisiensi pasar (market efficiency) diukur dari seberapa jauh harga-harga sekuritas menyimpang dari nilai intrinsiknya (Beaver, 1989). Dengan demikian suatu pasar yang efisien menurut konsep ini dapat didefinisikan sebagai pasar yang nilai-nilai sekuritasnya tidak menyimpang dari nilai-nilai intrinsiknya.

Perkembangan konsep efisiensi pasar selanjutnya tampaknya tidak berpegang pada konsep nilai intrinsik. Konsep efisiensi pasar lebih menjurus ke aspek akurasi dari return ekspektasi investor, ketersediaan informasi dan kecepatan pasar menyerap informasi tersebut.

\section{Signaling Theory}

Menurut teori yang dikembangkan oleh Modigliani dan Miller kebijakan dividen adalah tidak relevan dengan asumsi baik investor maupun manajer memiliki informasi yang sama atas kesemaptan investasi; sehingga investor dan manajer memiliki penilaian yang sama terhadap perusahaan dan kebijakan dividen atau kebijakan distribusi pendapatan di masa mendatang. Dalam kenyataannya, manajer cenderung memiliki informasi yang lebih baik dibanding investro tentang prospek perusahaan dibanding investor atau pemegang saham, atau dengan kata lain terjadi asymetri information (Brigham dan Gapenski, 1996; 445). Akibatnya investor menilai bahwa capital gain lebih berisiko dibanding dengan dividen dalam bentuk kas.

Pembayaran dividen dalam prakteknya selalu diikuti dengan kenaikan harga saham, sedangkan penurunan dividen akan diikuiti oleh penurunan harga saham. Kenyataan ini menunjukkan bahwa investor secara keseluruhan lebih menyukai pembayaran dividen daripada capital gain. Tetapi Modigliani dan Miller melihat kecenderungan ini dengan mengatakan bahwa karena perusahaan cenderung enggan untuk menurunkan tingkat dividen mereka, sehingga perusahaan hanya meningkatkan dividen apabila prospek keuntungan di masa mendatang baik. Modigliani dan Miller selanjutnya berpendapatan bahaw kenaikan dividen ini oleh investor dilihat sebagai tanda atau signal bahwa prospek perusahaan di masa mendatang akan lebih baik. Sebaliknya, penurunan dividen akan dilihat sebagai tanda bahwa prospek perusahaan menurun.

Akhirnya Modigliani dan Miller berkesimpulan bahwa reaksi investor terhadap perubahan dividen tidak berarti sebagai indikasi bahwa investor lebih menyukai dividen dibanding laba ditahan. Kenyataan bahwa harga saham berubah mengikuti perubahan dividen semata-mata karena adanya information content (Brigham dan Gapenski, 1996; 445). 


\section{Penelitian-penelitian Terdahulu}

Sebagian besar hasil penelitian yang menggunakan berbagai variasi model analisis membuktikan eksistensi muatan informasi tambahan arus kas operasi. Arus kas dari aktivitas operasi ini mempunyai pengaruh positif terhadap return saham. Pengaruh ini merupakan implikasi dari pengaruh arus kas sekarang terhadap prediksi arus kas masa depan. Wilson (1986) dan Rayburn (1986) menemukan muatan informasi tambahan arus kas operasi yang melebihi laba. Sementara Bernard dan Stober (1986) dan Livnat dan Zarrowin (1990) tidak menemukan adanya muatan informasi tambahan arus kas operasi dibandingkan dengan muatan informasi yang dimiliki laba.

Wahyuni (1998) maupun Ngaisah (1998) menghasilkan kesimpulan yang sama dari studi kasusnya di Bursa Efek Jakarta, yakni tidak berhasil mendapatkan hubungan yang signifikan antara laba, akrual dan arus kas operasi dengan return saham. Desain penelitian ini akan menguji kembali apakah koefisien total arus kas dari aktivitas operasi dalam persamaan (1) dan (2) sama dengan nol, artinya arus kas operasi tidak mempunyai hubungan yang signifikan terhadap return saham.

Menurut Livnat dan Zarrowin (1990), model Miller dan Rock (1985) dapat menambah kemampuan prediksi hubungan arus kas investasi dengan return saham. Secara general, kenaikan investasi memungkinkan timbulnya arus kas masa depan yang lebih tinggi apabila kinerja perusahaan baik. Namun apabila kinerja perusahaan rendah kenaikan investasi menyebabkan kenaikan resiko investasi yang berakibat pada penurunan arus kas masa depan. Hal ini memberikan konsekuensi adanya hubungan positif atau negatif antara arus kas investasi dengan return saham pada saat pengumuman investasi baru. Meski demikian, umumnya investor menolak investasi modal. Oleh karena itu dimungkinkan tidak adanya hubungan antara return saham dengan in- vestasi modal. Penelitian ini akan menguji apakah komponen arus kas dari aktivitas investasi mempunyai hubungan dengan return saham.

Livnat dan Zarrowin (1990) menemukan adanya hubungan yang signifikan antara kas dari aktivitas pendanaan dengan return saham. Secara teoritis, berdasarkan postulat Miller dan Modigliani (1961) struktural modal atau kebijakan dividen tidak relevan digunakan dalam penilaian sekuritas. Oleh karena itu nilai perusahaan tidak dipengaruhi oleh keputusannya untuk mendanai kebutuhan kasnya melalui penerbitan obligasi/surat utang, penerbitan saham biasa maupun saham prefern, Keputusan pendanaan tidak merefleksikan kinerja perusahaan yang dianggap sebagai tolak ukur nilai perusahaan. Dengan kata lain, nilai saham sebenarnya tidak dipengaruhi oleh kebijakan dividen yang diambil perusahaan. Komponen-komponen arus kas dari aktivitas pendanaan dianggap tidak memberikan kontribusi terhadap hubungan arus kas dengan return saham tahunan.

Ashiq Ali (1994) telah melakukan kajian empiris terhadap kandungan informasi dari laba, arus kas dan modal kerja dari operasi inkremental. Hasil penelitian yang dilakukan ternyata menunjukkan adanya kandungan informasi dari laba, arus kas dan modal kerja dari operasi inkremental. Dalam penelitian ini adanya kandungan informasi ditunjukkan oleh signifikansi koefisien regresi dari ketiga variabel tersebut sebagai variabel bebas, sedangkan return saham sebagai variabel terikat.

Kusuma (2001) melakukan penelitian tentang perbandingan kemampuan prediksi informasi laba dan arus kas di Australia. Model analisis data yang digunakan adalah 6 macam regresi linier dengan arus kas sebagai variabel terikat. Hasil penelitian ini menunjukkan bahwa, informasi laba bersih tidak lebih superior dari informasi laba bersih dalam memprediksi arus kas di masa mendatang. 


\section{Hipotesis}

Berdasarkan rumusan masalah dan tujuan dalam penelitian ini, maka hipotesis yang diajukan adalah sebagai berikut:

1. Laba memiliki kandungan informasi tambahan dalam memprediksi return saham.

2. Modal kerja operasi memiliki kandungan informasi tambahan dalam memprediksi return saham.

3. Arus kas operasi memiliki kandungan informasi tambahan dalam memprediksi return saham

\section{METODE PENELITIAN Populasi dan Sampel}

Populasi dari penelitian ini adalah seluruh perusahaan manufaktur yang tercatat di Bursa Efek Jakarta hingga tahun 2001. Sedangkan sampel dalam penelitian ini adalah sebagian dari perusahaan manufaktur tersebut. Metode pengambilan sampel (sampling) yang digunakan dalam penelitian ini purposive sampling. Adapun kriteria yang digunakan untuk memilih perusahaan sampel adalah sebagai berikut:

1. Sampel adalah perusahaan manufaktur yang terdaftar di BEJ sejak tahun 1997 hingga tahun 2001.

2. Sampel memiliki informasi yang diperlukan dalam penelitian dengan lengkap seperti: arus kas (operasi, investasi dan pendanaan), laba dan modal kerja dari operasi, serta harga saham.

3. Sampel mempublikasikan laporan keuangan yang telah diaudit.

4. Sampel memiliki frekuensi perdagangan saham yang tergolong cukup aktif.

\section{Definisi Istilah}

Definisi istilah yang digunakan dalam penelitian ini adalah sebagai berikut:

1. Laba (earning) adalah laba bersih sebelum peristiwa luar biasa dan penghentian operasi.

2. Modal kerja operasi adalah modal kerja yang dihitung dengan dasar arus kas operasi yaitu arus kas operasi dikurangi hutang lancar. Cara lain untuk menghitung modal kerja operasi adalah laba ditambah dengan penyesuaian-penyesuaian laba yang tidak mempengaruhi modal kerja.

3. Arus kas operasi adalah arus kas yang dihasilkan perusahaan dari kegiatan operasi utamanya.

\section{Metode Analisis Data}

Metode analisis data yang digunakan dalam penelitian ini adalah menggunakan model matematis yang telah digunakan oleh Ashiq Ali (1994). Adapun model matematis tersebut adalah sebagai berikut:

$$
\begin{aligned}
R E T_{i t}= & a_{o t}+a_{1 t} \Delta C F O_{i t}+a_{2 t} \Delta E_{i t} \\
& +a_{3 t} \Delta W C F O_{i t}+\mu_{i t}
\end{aligned}
$$

Keterangan simbol:

RET $_{\text {it }}$ : Return saham perusahaan i pada periode $\mathrm{t}$

$\triangle \mathrm{CFO}_{\mathrm{it}}:$ Perubahan arus kas dari operasi perusahaan i pada periode $\mathrm{t}$

$\Delta \mathrm{E}_{\mathrm{it}} \quad$ : Perubahan laba perusahaan $\mathrm{i}$ pada periode $t$

$\Delta \mathrm{WCFO}_{\mathrm{it}}$ : Perubahan modal kerja dari operasi perusahaan $\mathrm{i}$ pada periode $\mathrm{t}$

Sebelum model regresi di atas digunakan dalam pengujian hipotesis, terlebih dahulu model tersebut akan diuji apakah model tersebut memenuhi asumsi klasik atau tidak, yang mana asumsi ini merupakan asumsi yang mendasari analisis regresi.

Pengujian asumsi klasik ini dimaksudkan untuk memastikan bahwa model yang diperoleh benar-benar memenuhi asumsi dasar dalam analisis regresi yang meliputi asumsi: tidak terjadi autokorelasi, tidak terjadi multikolinearitas dan tidak terjadi heteroskedastisitas. 


\section{ANALISIS DATA DAN PENGUJIAN HIPOTESIS}

\section{Deskripsi Perusahaan Sampel}

Penelitian ini menggunakan sampel sebanyak 78 perusahaan manufaktur go public yang terdaftar di BEJ sejak tahun 1997 hingga tahun 2001. Pemilihan sampel dilakukan dengan purposive sampling, di mana kriteria yang digunakan dalam pemilihan sampel secara purposive ini adalah: (1) terdaftar di BEJ sejak tahun 1997 hingga tahun 2001, (2) memiliki informasi yang diperlukan dalam penelitian dengan lengkap seperti: arus kas operasi, laba dan modal kerja dari operasi, serta return saham, (3) mempublikasikan laporan keuangan yang telah diaudit, dan (4) memiliki frekuensi perdagangan saham yang tergolong cukup aktif. Adapun deskriptif perusahaan sampel yang berkaitan dengan variabel penelitian ini disajikan dalam Tabel 1.

\section{Analisis Regresi Linier Berganda}

Model matematis yang digunakan dalam penelitian ini untuk menyatakan pe- ngaruh dari perubahan arus kas, perubahan modal kerja operasi dan perubahan laba adalah model regresi linier berganda. Adapun model tersebut secara umum dapat dituliskan sebagai berikut:

$$
\begin{aligned}
R E T_{i t}= & a_{o t}+a_{1 t} \Delta C F O_{i t}+a_{2 t} \Delta E_{i t} \\
& +a_{3 t} \Delta W C F O_{i t}+\mu_{i t}
\end{aligned}
$$

Keterangan simbol:

RET $_{\text {it }}$ : Return saham perusahaan i pada periode $\mathrm{t}$

$\triangle \mathrm{CFO}_{\text {it }} \quad$ :Perubahan arus kas dari operasi perusahaan i pada periode $t$

$\Delta \mathrm{E}_{\mathrm{it}} \quad$ :Perubahan laba perusahaan $\mathrm{i}$ pada periode $\mathrm{t}$

$\triangle \mathrm{WCFO}_{\text {it }}$ : Perubahan modal kerja dari operasi perusahaan i pada periode $\mathrm{t}$

$\mu_{\text {it }} \quad$ :Disturbance error

Hasil analisis regresi dengan bantuan program SPSS 11.5 terhadap data 58 perusahaan untuk periode tahun 1997 hingga tahun 2001 disajikan pada Tabel 2.

Tabel 1. Deskripsi Variabel Penelitian

\begin{tabular}{|l|c|r|r|c|}
\hline & $\begin{array}{c}\text { Return } \\
\text { Saham }\end{array}$ & $\begin{array}{c}\text { Perubahan } \\
\text { Arus Kas (*) }\end{array}$ & $\begin{array}{c}\text { Perubahan } \\
\text { Modal Kerja }\end{array}$ & $\begin{array}{c}\text { Perubahan } \\
\text { Laba }\end{array}$ \\
\hline \hline Minimum & $-0,0524$ & -1.143 .370 & 2.073 & 608 \\
\hline Maksimum & 0,5605 & 3.231 .764 & 112.296 .894 & 9.117 .134 \\
\hline Rata-rata & 0,2621 & 65.137 .171 & 2.298 .201 & 258.724 \\
\hline Std. Deviasi & 0,0483 & 232.881 .635 & 7.391 .759 & 911.188 \\
\hline
\end{tabular}

Keterangan: (*) dalam ribuan rupiah. Data dalam rupiah terdeflasi

Tabel 2. Hasil Analisis Regresi

\begin{tabular}{|l|c|r|c|}
\hline & Koefisien regresi & \multicolumn{1}{c|}{ thitung } & \multicolumn{1}{c|}{$\mathbf{p}$} \\
\hline \hline Konstanta & 0.2509 & & \\
\hline Perubahan Arus Kas $(\Delta \mathrm{CFO})$ & $1.012 \times 10^{-13}$ & 11.740 & 0.000 \\
\hline Perubahan Laba $(\Delta \mathrm{E})$ & $7.610 \times 10^{-10}$ & 4.531 & 0.000 \\
\hline Perubahan Modal Kerja $(\Delta \mathrm{WCFO})$ & $1.109 \times 10^{-08}$ & 2.495 & 0.013 \\
\hline $\mathrm{R}=0.592 ; \mathrm{R}^{2}=0.351$ & & \\
Fhitung $=69.541 ; \mathrm{p}=0.000$ & & & \\
Durbin-Watson $=2.027$ & & & \\
\hline
\end{tabular}




\section{Pengujian Asumsi Klasik}

Sebelum model regresi di atas digunakan dalam pengujian hipotesis, terlebih dahulu model tersebut akan diuji apakah model tersebut memenuhi asumsi klasik atau tidak, yang mana asumsi ini merupakan asumsi yang mendasari analisis regresi. Pengujian asumsi klasik ini dimaksudkan untuk memastikan bahwa model yang diperoleh benar-benar memenuhi asumsi dasar dalam analisis regresi yang meliputi asumsi: tidak terjadi autokorelasi, tidak terjadi multikolinearitas dan tidak terjadi heteroskedastisitas.

\section{Pengujian Autokorelasi}

Berdasarkan hasil analisis dengan program SPSS 11.5 diperoleh besarnya nilai statistik Durbin Watson, $d=2.027$. Sedangkan untuk jumlah sampel $n=390, k^{\prime}=3$ dan tingkat signifikansi $\alpha=5 \%$ dari Tabel $\mathrm{d}$ diperoleh nilai $\mathrm{d}_{\mathrm{L}}=1.738$ dan $\mathrm{d}_{\mathrm{U}}=1.799$.

Nilai $d=2.027$ dan $d_{U}=1.799$, jika dibandingkan ternyata nilai $d>d_{U}$ maka keputusannya adalah tidak menolak Ho, dengan demikian Ho yang menyatakan tidak terjadi autokorelasi tidak ditolak. Berdasarkan hasil pengujian ini, ternyata pada tingkat signifikansi $5 \%$ data yang diolah tersebut tidak menunjukkan adanya gejala autokorelasi, sehingga asumsi klasik mengenai tidak terjadinya gejala autokorelasi dapat terpenuhi oleh model yang diperoleh.

\section{Pengujian Uji Heteroskedastisitas}

Berdasarkan hasil analisis data yang telah dilakukan dengan bantuan program SPSS 11.5 diperoleh besarnya koefisien korelasi Spearman antara variabel bebas dengan nilai mutlak residu dapat dilihat pada Tabel 3.
Untuk jumlah sampel $n=390$ dan tingkat signifikansi $\alpha=5 \%$ dari Tabel $r_{s}$ diperoleh nilai $r_{s \text { tabel }}=0.364$. Jika masingmasing nilai korelasi Spearman dalam Tabel 3 dibandingkan dengan nilai $r_{s}$ tabel, ternyata nilai masing-masing $r_{s}<r_{\text {stabel }}(0.364)$; hal ini menunjukkan bahwa masing-masing korelasi Spearman dalam Tabel 3 tidak signifikan.

Berdasarkan hasil uji signifikansi koefisien korelasi Spearman (rs) antara variabel bebas dengan nilai mutlak residu tersebut, maka dapat disimpulkan bahwa data yang dianalisis tidak mengandung gejala heterokedastisitas. Dengan demikian asumsi klasik mengenai tidak terjadinya heteroskedastisitas dapat diterima.

\section{Pengujian Multikolinearitas}

Berdasarkan hasil analisis data dengan bantuan program SPSS 11.5 diperoleh besarnya nilai VIF masing-masing variabel bebas adalah tampak pada Tabel 4 . Dari hasil analisis data tersebut, tampak bahwa, masing-masing variabel bebas mempunyai VIF kurang dari 10. Dengan ini, data yang diolah menunjukkan tidak adanya gejala multikolineraitas.

\section{Pengujian Hipotesis Pengujian Hipotesis Pertama}

Hipotesis pertama dalam penelitian ini menduga bahwa, Perubahan laba memiliki kandungan informasi tambahan dalam memprediksi return saham. Pengujian terhadap ada tidaknya kandungan informasi yang terdapat dalam informasi laba tersebut dilakukan melalui pengujian terhadap signifikansi koefisien regresi dari variabel Laba. Jika koefisien tersebut signifikan, maka dapat diartikan bahwa variabel Laba memiliki kandungan informasi dalam memprediksi return saha, atau dengan kata lain, laba berpengaruh terhadap return saham. 
Tabel 3.

Koefisien Korelasi Spearman antar Variabel Bebas dengan Nilai Mutlak Residu

\begin{tabular}{|l|c|c|}
\hline \multicolumn{1}{|c|}{ Variabel Bebas } & Koefisien Korelasi (rs) & $\mathbf{p}$ \\
\hline \hline Perubahan Arus Kas $(\Delta \mathrm{CFO})$ & -0.015 & 0.236 \\
\hline Perubahan Laba $(\Delta \mathrm{E})$ & 0.042 & 0.113 \\
\hline Perubahan Modal Kerja $(\Delta \mathrm{WCFO})$ & 0.069 & 0.078 \\
\hline
\end{tabular}

Tabel 4.

VIF masing-masing Variabel Bebas

\begin{tabular}{|l|c|}
\hline \multicolumn{1}{|c|}{$\begin{array}{c}\text { Variabel } \\
\text { Bebas }\end{array}$} & VIF \\
\hline \hline Perubahan Arus Kas $(\Delta \mathrm{CFO})$ & 1.027 \\
\hline Perubahan Laba $(\Delta \mathrm{E})$ & 1.267 \\
\hline Perubahan Modal Kerja $(\Delta \mathrm{WCFO})$ & 1.295 \\
\hline
\end{tabular}

Formulasi hipotesis dari hipotesis pertama ini dapat dinyatakan sebagai berikut:

Ho : $b_{1}=0$ Perubahan laba tidak memiliki kandungan informasi tambahan dalam memprediksi return saham.

Ha : $b_{1} \neq 0$ Perubahan laba memiliki kandungan informasi tambahan dalam memprediksi return saham.

Besarnya nilai koefisien regresi untuk variabel Perubahan laba adalah $b_{1}=$ $7.610 \times 10^{-10}$; nilai $t_{\text {hitung }}=4.531$; dan $\mathrm{p}=0.000$. Pada tingkat signifikansi $\alpha=5 \%$; maka koefisien regresi tersebut signifikan (tidak dapat diabaikan), karena $\mathrm{p}=0.000<0.05$.

Berdasarkan hasil pengujian hipotesis di atas maka dapat disimpulkan bahwa, Perubahan laba memiliki kandungan informasi tambahan dalam memprediksi return saham; sehingga hipotesis pertama penelitian ini dapat dibuktikan kebenarannya.

\section{Pengujian Hipotesis Kedua}

Hipotesis kedua dalam penelitian ini menduga bahwa, perubahan modal kerja operasi memiliki kandungan informasi tambahan dalam memprediksi return saham. Pengujian terhadap ada tidaknya kandungan informasi yang terdapat dalam informasi modal kerja tersebut dilakukan melalui pe- ngujian terhadap signifikansi koefisien regresi dari variabel Perubahan modal kerja. Jika koefisien tersebut signifikan, maka dapat diartikan bahwa variabel Perubahan modal kerja memiliki kandungan informasi dalam memprediksi return saha, atau dengan kata lain, perubahan modal kerja berpengaruh terhadap return saham.

Formulasi hipotesis dari hipotesis pertama ini dapat dinyatakan sebagai berikut:

Ho : $b_{2}=0$ Perubahan modal kerja tidak memiliki kandungan informasi tambahan dalam memprediksi return saham.

Ha : $b_{2} \neq 0$ Perubahan modal kerja memiliki kandungan informasi tambahan dalam memprediksi return saham.

Besarnya nilai koefisien regresi untuk variabel Modal kerja adalah $\mathrm{b}_{2}=$ $7.610 \times 10^{-10}$; nilai $\mathrm{t}_{\text {hitung }}=4.531$; dan $\mathrm{p}=0.000$. Pada tingkat signifikansi $\alpha=5 \%$; maka koefisien regresi tersebut signifikan (tidak dapat diabaikan), karena $\mathrm{p}=0.000<0.05$.

Berdasarkan hasil pengujian hipotesis di atas maka dapat disimpulkan bahwa, perubahan modal kerja memiliki kandungan informasi tambahan dalam memprediksi return saham; sehingga hipotesis kedua penelitian ini dapat dibuktikan kebenarannya. 


\section{Pengujian Hipotesis Ketiga}

Hipotesis ketiga dalam penelitian ini menduga bahwa, perubahan arus kas operasi memiliki kandungan informasi tambahan dalam memprediksi return saham. Pengujian terhadap ada tidaknya kandungan informasi yang terdapat dalam informasi perubahan arus kas operasi tersebut dilakukan melalui pengujian terhadap signifikansi koefisien regresi dari variabel perubahan arus kas operasi. Jika koefisien tersebut signifikan, maka dapat diartikan bahwa variabel perubahan arus kas operasi memiliki kandungan informasi dalam memprediksi return saha, atau dengan kata lain, perubahan arus kas operasi berpengaruh terhadap return saham.

Formulasi hipotesis dari hipotesis pertama ini dapat dinyatakan sebagai berikut:

Ho : $b_{3}=0$ Perubahan arus kas operasi tidak memiliki kandungan informasi tambahan dalam memprediksi return saham.

Ha : $b_{3} \neq 0$ Perubahan arus kas operasi memiliki kandungan informasi tambahan dalam memprediksi return saham.

Besarnya nilai koefisien regresi untuk variabel Perubahan arus kas operasi adalah $b_{3}=1.012 \times 10^{-13}$; nilai $t_{\text {hitung }}=11.740$; dan $\mathrm{p}=0.000$. Pada tingkat signifikansi $\alpha=5 \%$; maka koefisien regresi tersebut signifikan (tidak dapat diabaikan), karena $\mathrm{p}=0.000<0.05$.

Berdasarkan hasil pengujian hipotesis di atas maka dapat disimpulkan bahwa, perubahan arus kas operasi memiliki kandungan informasi tambahan dalam memprediksi return saham; sehingga hipotesis ketiga penelitian ini dapat dibuktikan kebenarannya.

\section{SIMPULAN DAN SARAN}

Simpulan

1. Perubahan laba memiliki kandungan informasi tambahan dalam memprediksi return saham $\quad\left(t_{\text {hitung }}=4.531\right.$; dan $\mathrm{p}=0.000$ ). Hal ini menunjukkan bahwa perubahan laba dapat digunakan sebagai variabel prediktor dalam memprediksi return saham. Tinggi rendahnya return saham tergantung pada tinggi rendahnya perubahan laba.

2. Perubahan modal kerja operasi memiliki kandungan informasi tambahan dalam memprediksi return saham ( $t_{\text {hitung }}=2.495$; dan $\mathrm{p}=0.000$ ). Hal ini menunjukkan bahwa perubahan modal kerja operasi dapat digunakan sebagai variabel prediktor dalam memprediksi return saham. Tinggi rendahnya return saham tergantung pada tinggi rendahnya perubahan modal kerja operasi.

3. Perubahan arus kas operasi memiliki kandungan informasi tambahan dalam memprediksi return saham ( $\mathrm{t}_{\text {hitung }}=$ 11.740; dan $\mathrm{p}=0.000)$. Hal ini menunjukkan bahwa perubahan arus kas operasi dapat digunakan sebagai variabel prediktor dalam memprediksi return saham. Tinggi rendahnya return saham tergantung pada tinggi rendahnya perubahan arus kas operasi.

\section{Saran}

1. Model regresi yang diperoleh ternyata secara statistika memiliki kemampuan untuk melakukan prediksi terhadap return saham perusahaan-perusahaan manufaktur go public. Oleh karena itu, pihak-pihak yang memerlukan informasi mengenai return saham periode yang akan datang dapat menggunakan model regresi ini untuk mencari nilai pendekatan atau peramalan terhadap return tersebut.

2. Kemampuan meramalkan return saham untuk periode yang akan yang dimiliki oleh model regresi tersebut didasarkan pada hasil pengujian signifikansi koefisien regersinya saja, tanpa memandang parameter-parameter lain. Tetapi jika kemampuan meramal tersebut ditinjau dari besarnya koefisien derter- 
minasi model regresi yaitu $\mathrm{R}^{2}=0,351$; yang berarti hanya $35,1 \%$ perubahan atau variasi dalam return saham yang dapat dijelaskan oleh model; sedangkan pengaruh dari variabel lain terhadap variasi return saham adalah sebesar 64,9\%. Hal ini menunjukkan bahwa model yang diperoleh memiliki ke- mampuan prediksi yang tergolong sedang, oleh karena itu, bagi pihak lain yang berminat untuk mengkaji lanjut penelitian ini dapat menyempurnakannya melalui penambahnan beberapa variabel bebas baru; sehingga dapat meningkatkan kemampuan prediksi model tersebut.

\section{DAFTAR PUSTAKA}

Ali, Ashiq. (1994) "The Incremental Information Content of Earnings, Working Capital from Operations, and Cash Flows", Journal of Accounting Research, Vol. 32, No. 1, Spring 1994, pp. 61-74.

Baridwan, Zaki. (1997). Intermediate Accounting, Edisi 7, BPFE, Yogyakarta.

Baridwan, Zaki dan Parawiyati, (1998). "Kemampuan Laba dan Arus Kas dalam Memprediksi Laba dan Arus Kas Perusahaan Go Publik di Indonesia", Jurnal Riset Akuntansi, Volume 1, Nomor 1, Januari, 1998.

Beaver, W. H., (1989). Financial Reporting: An Accounting Revolution, Englewood Cliffs, New York.

Brigham, Eugene F. and Louis C. Gapenski. (1996). Intermediate Financial Management., Dryden Press, New York.

Wilson, Ray and Rayburn Watts, (1986). "Some Time Series Properties on Accounting Income", Journal of Finance, June 1986, 663-682.

Bowen, Robert M., David Burgstahler, and Lane A. Daley, (1986). "Eviedence on the Relationships between Earnings and Various Measures of Cash Flow", The Accounting Review, Vol. LXI, No. 4 October, 713-725.

Donald, Keyso dan Weygandt. (1995). Akuntansi Intermediate, Jilid I, Edisi Ketujuh, Binarupa Aksara, Jakarta.

Fama, E., (1970). "Efficient Capital Market: A Review of Theory and Empirical Work", Journal of Finance, Vol. 25, pp. 383-417.

Finger, Catherine A., (1994). "The Ability of Earnings to Predict Future Earnings and Cash Flow", Journal of Accounting Research, Vol. 32, No. 2, Autum 1994, pp. 210-223.

Foaster, G, (1986). Financial Statement Analysis, Englewood Cliffs, New York.

Gujarati, Damodar N., (1995). Basic Econometric. Third Edition, McGraw Hill Book Company, New York.

Husnan, Suad. (1993). Dasar-dasar Teori Portofolio. Edisi Pertama, UPP AMP YKPN, Yogyakarta.

Ikatan Akuntansi Indonesia. (1994). Standar Akuntansi Keuangan, Buku Satu, Salemba Empat, Jakarta. 
Handojo Budi Rahardjo \& Hadri Kusuma

Ikatan Akuntan Indonesia, (2002). Standar Akuntansi Keuangan Per 1 April 2002, Salemba Empat, Jakarta.

Jogiyanto, H.M., (1998). Teori Portofolio dan Analisis Investasi, Edisi Pertama, BPFE Yogyakarta.

Jogiyanto, H.M., (2000). Teori Portofolio dan Analisis Investasi, Edisi Kedua, BPFE Yogyakarta.

Jones, Charles P., (1995). Investment: Analysis and Management, Fifth Edition, John Wiley and Sons, Inc., New York.

Livnat, J.; and P. Zarowin. (1990). "The Incremental Information Content of Cash Flow Components", Journal of Accuounting and Economics, Vol. 12, pp. 25-46.

Munawir, Slamet, (2002). Analisis Informasi Keuangan, Liberty, Yogyakarta. 